\title{
Social Learning Management System (Slms) For Technical Vocational Education And Training (Tvet) Program With Filtered Foul Words
}

\author{
Raquel SALAZAR \\ Polytechnic University of the Philippines - Institute of Technology \\ rgsalazar@pup.edu.ph
}

Article History: Received: 10 November 2020; Revised 12 January 2021 Accepted: 27 January 2021; Published online: 5 April 2021

\begin{abstract}
This study aimed to develop, deploy and evaluate a Social Learning Management System for the Technical Vocational Education Training (TVET) Programs with Filtered Foul Words as a tool for the faculty and students in the institution. Specifically, this sought to identify the challenges met and experienced by the respondents in conducting academic services and teaching-learning activities; levels of satisfaction on the features offered by the proposed system; and the issues encountered in the facilitation of the proposed system.

After developing SLMS, researcher-made questionnaire was administered to the randomly selected 338 students and 14 faculty members from the Polytechnic University of the Philippines Institute of Technology to evaluate the proposed system. Rate and Weighted Mean were utilized in treating the information.

The study reveals the challenges met and experienced by the respondents in conducting academic services and teaching learning activities. Aside from that, respondents are very satisfied in the usability, functionality, efficiency, reliability and portability features of the developed system. There were very minimal number of problems during the deployment of the system

Keywords: Social Learning, Learning Management System, Technical Vocational Education and Training, Filtered Four
\end{abstract} Words

\section{Introduction}

Information systems give chances to improve understudy learning by giving exchange approaches to students to utilize innovation in learning conditions and to upgrade the board abilities of instructors just as school overseers. Information systems provide opportunities to improve student learning by providing alternate ways for learners to use technology in learning environments and to enhance management capabilities of teachers as well as school administrators. Information system is an important tool in delivering educational services which educational innovators must give emphasis on producing computer learning system facility.

Learning management system (LMS), which is available in some educational institutions, allows anyone to create, track, manage and distribute learning materials of any kind. In addition, LMS is considered as an integral asset for associations that practice preparing; and offices that are hoping to show signs of improvement handle on proceeding with instruction.

Its effect has been felt for the most part outside of the traditional education institutions; however, the equivalent technological and market powers are drastically changing the present classroom also. Thus, educational administrators must have a concentration on how these changes will be properly accepted and utilize by their institutions. LMS gives the learning institutions potentialities to improve their educational services in almost all facet. On this context, social learning management system was undertaken.

\section{Materials And Methods}

Descriptive method of research was used. This strategy, as indicated by Zikmund (2003), is to depict attributes of an issue of a populace or phenomenon. It looks to decide the responses to who, what, when, where, and how questions.

The researcher described the evaluation of the online learning management system implemented as academic application for teaching, learning, and administrative facility. This research used quantitative research approach. Quantitative research approach concentrates more in tallying and arranging highlights and developing measurable models and figures to clarify what is watched (Shuttleworth, 2016). The subject of this study was to evaluate responses on the levels of efficiency and satisfaction perceived by the faculty members and the students on the deployed system. 
The population of students of the Polytechnic University of the Philippines Institute of Technology is 2185 . With the use of the courses offered at Itech as the strata of distribution, the research lifted random samples from each; therefore, the inspecting method is called stratified random sampling. This testing includes the division of a populace into littler gatherings known as strata. Strata are framed dependent on individuals' shared qualities or attributes. In this study, the strata are the six (6) recognized courses.

The expected population of the faculty members was fourteen (14). Purposively, the respondents were regular and permanent employees.

Table 1Distribution of Respondents per Diploma Course

\begin{tabular}{|c|c|c|c|}
\hline $\begin{array}{l}\text { Díploma } \\
\text { Program }\end{array}$ & Population & Percent & $\begin{array}{l}\text { Sample } \\
\text { ize }\end{array}$ \\
\hline DCET & 411 & $18.81 \%$ & 64 \\
\hline DICT & 720 & $32.95 \%$ & 111 \\
\hline DEET & 124 & $5.68 \%$ & 19 \\
\hline DMET & 136 & $6.22 \%$ & 21 \\
\hline DECET & 186 & $8.51 \%$ & 29 \\
\hline DOMT & 608 & $27.83 \%$ & 94 \\
\hline TOTAL & 2,185 & $\%^{100.00}$ & 338 \\
\hline
\end{tabular}

\section{Results and Discussion}

Table 2 Academic Service Challenges Faced by Faculty

\begin{tabular}{|c|c|c|}
\hline Indicator & Weighted Mean & Verbal Interpretation \\
\hline $\begin{array}{l}\text { 1. The distribution of teaching tools is } \\
\text { inefficient. }\end{array}$ & 4.76 & Always \\
\hline $\begin{array}{l}\text { 2. Checking of quizzes and examinations } \\
\text { is inaccurate and time-consuming }\end{array}$ & 4.53 & Always \\
\hline $\begin{array}{l}\text { 3. The sources of subject matter in } \\
\text { discussion are not updated. }\end{array}$ & 4.53 & Always \\
\hline $\begin{array}{l}\text { 4. The research materials and links are } \\
\text { not available. }\end{array}$ & 4.46 & Always \\
\hline 5. The time in discussion is limited & 4.84 & Always \\
\hline $\begin{array}{l}\text { 6. Managing and scheduling of activities } \\
\text { are not organized and implemented. }\end{array}$ & 4.15 & Often \\
\hline $\begin{array}{l}\text { 7. Private conversations and counselling } \\
\text { students are not possible. }\end{array}$ & 4.69 & Always \\
\hline $\begin{array}{l}\text { 8. The submitted documents are not } \\
\text { properly secured and documented. }\end{array}$ & 4.69 & Always \\
\hline
\end{tabular}

Table 2 shows the weighted mean distribution of responses of faculty on the academic service challenges. Without the proposed system the academic services rendered by the faculty were facing different challenges. The "limitation of time in discussion" has obtained the weighted mean of 4.84 with verbal understanding "always." The inefficiency of the distribution of teaching tools is "always" with the weighted mean of 4.76. Subsequently, the impossibility of conversations and counselling with the students gained 4.69, "always;" and the submission of documents were not "always" properly secured and documented with the same weighted mean of 4.69. Discussing obsolete subject matter; and rendering time on checking quizzes and examinations with inaccurate results are 4.53 with the interpretation "always". Likewise, there is a very low availability of research materials as shown in the computed weighted mean 4.45, "always." Finally, with the weighted mean of 4.15 , managing and scheduling of activities are not "often" organized and implemented. 
Table 3 Teaching-Learning Challenges Faced by Students

\begin{tabular}{|c|c|c|}
\hline Indicator & Weighted Mean & Verbal Interpretation \\
\hline $\begin{array}{l}\text { 1. The distribution of learning materials } \\
\text { is inefficient. }\end{array}$ & 3.83 & Often \\
\hline $\begin{array}{l}\text { 2. Feedbacks and results of examinations } \\
\text { are inaccurate and not immediate. }\end{array}$ & 3.78 & Often \\
\hline $\begin{array}{l}\text { 3. The sources of lessons in activities are } \\
\text { not updated. }\end{array}$ & 3.78 & Often \\
\hline $\begin{array}{l}\text { 4. The research materials and links are } \\
\text { not accessible. }\end{array}$ & 3.69 & Often \\
\hline 5. The time in activities is limited. & 3.90 & Often \\
\hline $\begin{array}{l}\text { 6. The schedules of activities are not } \\
\text { organized and participants are not informed. }\end{array}$ & 3.26 & Sometimes \\
\hline $\begin{array}{l}\text { 7. Consulting and approaching teachers } \\
\text { are not possible. }\end{array}$ & 3.75 & Often \\
\hline $\begin{array}{l}\text { 8. The submitted requirements are not } \\
\text { immediately received on time. }\end{array}$ & 4.04 & Often \\
\hline
\end{tabular}

Students' submission of their requirements is not "often" received on time with the weighted mean of 4.04. Their classroom activities are "'often" limited of time which has gained a weighted mean of 3.90. Similarly, there is an "often" inefficiency of distribution of learning materials which has obtained 3.83. "Their lessons are not 'often' updated"; "Feedbacks and results of examinations are 'often' received immediately"; "Consulting and approaching teachers are 'often' possible"; "The research materials and links are not 'often' accessible"; and "The schedules of activities are not 'sometimes' organized and participants are not 'sometimes' informed" gained respectively the weighted means of $3.78,3.78,3.75,3.69$, and 3.26.

Table 4 Respondents Level of Satisfaction on the feature of the System

\begin{tabular}{|c|c|c|c|c|}
\hline \multirow[t]{3}{*}{ Features } & \multicolumn{2}{|l|}{ Faculty } & \multicolumn{2}{|l|}{ Student } \\
\hline & Weighted Mean & Verbal & Weighted Mean & Verbal \\
\hline & & Interpretation & & Interpretation \\
\hline Usability & 4.82 & Very Satisfied & 4.34 & Very Satisfied \\
\hline Functionality & 4.72 & Very Satisfied & 4.35 & Very Satisfied \\
\hline Efficiency & 4.72 & Very Satisfied & 4.34 & Very Satisfied \\
\hline Reliability & 4.72 & Very Satisfied & 4.34 & Very Satisfied \\
\hline Portability & 4.63 & Very Satisfied & 4.61 & Very Satisfied \\
\hline Overall & 4.72 & Very Satisfied & 4.39 & Very Satisfied \\
\hline
\end{tabular}

Table 4 shows the overall faculty level of satisfaction on the features of the system. The system's usability gained 4.82, very satisfied; functionality, 4.73, very satisfied; efficiency, 4.73, very satisfied; reliability, 4.69, very satisfied; and portability, 4.63 , very satisfied. The respondents are very satisfied, 4.72 , on the system's features. Evaluation of the students with respect to level of satisfaction: usability, 4.34; functionality, 4.35; 
efficiency, 4.34; reliability, 4.34; and portability, 4.61 the overall evaluated score is 4.39 , very satisfied.

These five characteristics of the international standards for evaluation of software's quality control, assurance and process improvement were sufficed as these were evaluated by the users (faculty and students). This ensures that the proposed system reached excellently the expectation of the institution's objectives using the international standards.

Table 5 Respondents Issues Encountered in the Facilitation of the Proposed System

\begin{tabular}{|c|c|c|c|c|}
\hline \multirow[b]{2}{*}{ Indicator } & \multicolumn{2}{|l|}{ Faculty } & \multicolumn{2}{|l|}{ Student } \\
\hline & $\begin{array}{l}\text { Freque } \\
\text { ncy }\end{array}$ & $\begin{array}{l}\text { Perc } \\
\text { ent }\end{array}$ & $\begin{array}{l}\text { Freque } \\
\text { ncy }\end{array}$ & $\begin{array}{l}\text { Perc } \\
\text { ent }\end{array}$ \\
\hline $\begin{array}{l}\text { 1. The number of computers used } \\
\text { during the facilitation of the system were not } \\
\text { sufficient. }\end{array}$ & 2 & 14 & 149 & 44 \\
\hline $\begin{array}{l}\text { 2. The technical support person for the } \\
\text { system was needed. }\end{array}$ & 2 & 14 & 138 & 41 \\
\hline $\begin{array}{l}\text { 3. The visual aspects and graphical } \\
\text { technicalities of the system are not } \\
\text { appropriate. }\end{array}$ & 0 & 0 & 117 & 35 \\
\hline $\begin{array}{l}\text { 4. Technical inputs and data were not } \\
\text { accurately responded by the system. }\end{array}$ & 3 & 21 & 104 & 31 \\
\hline $\begin{array}{l}\text { 5. The quizzes and examinations were } \\
\text { not properly implemented. }\end{array}$ & 0 & 0 & 104 & 31 \\
\hline $\begin{array}{l}\text { 6. Scores and quantitative evaluations } \\
\text { were not correctly computed. }\end{array}$ & 0 & 0 & 87 & 26 \\
\hline $\begin{array}{l}\text { 7. The subjects used in the content } \\
\text { were not appropriate for the system }\end{array}$ & 1 & 7 & 95 & 28 \\
\hline $\begin{array}{l}\text { 8. The organization of the lesson was } \\
\text { difficult to follow. }\end{array}$ & 0 & 0 & 80 & 24 \\
\hline $\begin{array}{l}\text { 9. Various functions of the system } \\
\text { were not properly integrated. }\end{array}$ & 1 & 7 & 91 & 27 \\
\hline $\begin{array}{l}\text { 10. The links provided in the material } \\
\text { are not clearly visible. }\end{array}$ & 0 & 0 & 90 & 27 \\
\hline Overall Frequency \& and Percentage & 1.69 & er ${ }^{\text {Nev }}$ & 2.11 & om $^{\text {Seld }}$ \\
\hline
\end{tabular}

1.

Table 5 shows the respondent's issues encountered in the facilitation of the proposed system. Three (3) or $21 \%$ of the faculty respondents say that, "Technical inputs and data were not accurately responded by the system." Two (2) or 14\% of them say that, "The number of computers used during the facilitation of the system were not sufficient"; and two (2) or 14\% of them responded that, "The technical support person for system was needed." There were some subjects used that were not appropriate according to one (1) or 7 percent of the faculty respondents. Finally, "Various functions of the system were not properly integrated" according to one (1) or 7 percent of the faculty respondents.

One hundred forty-nine (149) or $44 \%$ of the student respondents say that "The number of computers used during the facilitation of the system were not sufficient." One hundred thirty-eight (138) or $41 \%$ of them agree that the system needed technical support. "The visual aspects and graphical technicalities of the system are not appropriate" based on the one hundred seventeen (117) or 35\% of the student respondents. One hundred four (104) or $31 \%$ of them say that, "Technical inputs and data were not accurately responded by the system" and "The quizzes and examinations were not properly implemented." According to the ninety-five (95) or 28\% of the student respondents, the subjects used were not appropriate for the system. Various functions of the system were not properly integrated based on the ninety-one (91) or $27 \%$ of the respondents, while the links provided in the material are not clearly visible agreed by the ninety (90) of the respondents. Lastly, eighty-seven (87) or 26\% of the respondents say that, "Scores and quantitative evaluations were not correctly computed."

The data reveal that there were very minimal number of problems during the deployment of the system. External difficulties and factors were expected to be experienced by the researcher and the institution. The ratio of number of students and computer is evident. 


\section{Conclusions}

\section{Conclusion}

The study reveals the challenges met and experienced by the respondents in conducting academic services and teaching learning activities. Aside from that, respondents are very satisfied in the usability, functionality, efficiency, reliability and portability features of the developed system. There was exceptionally insignificant number of issues during the deployment of the system.

\section{RECOMMENDATION}

The administrators should consider integrating information technology to enhance alternative ways of teaching opportunities of the faculty and learning venues of the students. Administration should also invest to information technology facility for better implementation of technologically enhanced curriculum.

Faculty members should undergo orientation and training on using learning management system as part of their teaching methodologies and strategies. They should be trained on utilizing the system to maximize the features and benefits in facilitating classroom instruction using LMS. Faculty and technical person should be provided with system's guide. Subjects should be prepared appropriately to the system's features.

Students should be made aware of the learning opportunities which they can gain from LMS appropriate for technical vocational courses. They should be consistently and persistently guided by the administration and faculty members on the proper usage of the system. They should be provided with students' system guide.

\section{References}

Ales Popovic, P. S. (2009). InformationResearch. Retrieved from Impact of Business Intelligence Systems Maturity on Information Quality: http://nile.lub.lu.se/ojs/index.php/infores/article/view/1468

Bajo, R. (2013, March 5). Educational Technology. Retrieved from Benefits of Educational Technology: https://rynbaj.wordpress.com/type/aside/

Commendador, Guillo (2014, December). International Journal of Information and Education Technology. Retrieved from A Community Cloud-Based Course Management System Using Platform as a Service (PaaS) Model for Higher Educational Institutions: http://www.ijiet.org/papers/454-F015.pdf

BusinessDictionary. (2016). BusinessDictionary. Retrieved from Usability: http://www.businessdictionary.com/definition/usability.html

Castillo, C. (2012, December 13). DepEd. Retrieved from Learning Management System: http://www.elementary.ph/learning-management-system-lms

Dacuycuy-Pacio, R. (2013). International Journal of Innovative Interdisciplinary Research . Retrieved from nline Student Information System of Benguet State University (OSIS-BSU), Philippines: http://www.auamii.com/jiir/vol-01/issue-04/4pacio.pdf

Dang, Robertson(2010, August). ccsenet. Retrieved from Impacts of Learning Management System on Learner Autonomy in EFL Learning: http://files.eric.ed.gov/fulltext/EJ1065904.pdf

Dasig Jr., D. (2014, August). International Journal of Business Information Systems Strategies (IJBISS) . Retrieved from A study on the sectors of economy serviced by pre-industry system developers among companies in Metro Manila: A tool for Business Reengineering: https://arxiv.org/ftp/arxiv/papers/1409/1409.7277.pdf

Dictionary. (2016). Dictionary. Retrieved from Efficiency: http://www.dictionary.com/browse/efficiency Dimasuay, Pabro (2009). ijcim. Retrieved from Use of Learning Management: A University of the $\begin{array}{lllll}\text { Philippines } & \text { Los } & \text { Banos } & \text { (UPLB) } & \text { Classroom }\end{array}$ http://www.ijcim.th.org/SpecialEditions/v17nSP3/22_Full_Lynie\%20B.\%20Dimasuay.pdf

Ebardo, R. A. (2010). ijcim. Retrieved from The Effect of Web-Based Learning Management System on Knowledge Acquisition of Information Technology Student of Jose Rizal University: http://ijcim.th.org/SpecialEditions/v17nSP3/09_Full_Ryan\%20A.\%20Ebardo.pdf

Emelyanova, Voronina(2014). The International Review of research in Open and Distance Learning. Retrieved from Introducing a Learning Management System at a Russian University: Students and Teachers Perceptions: http://www.irrodl.org/index.php/irrodl/article/viewFile/1701/2819

training Company need an LMS for?: https://www.upsidelearning.com/blog/index.php/2009/07/21/learningmanagement-what-does-a-training-company-need-an-lms-for/

Golden, R. (2016). Small Business. Retrieved from What Are the Three Most Important Characteristics of a Small Business Computer System?: http://smallbusiness.chron.com/three-important-characteristics-smallbusiness-computer-system-65183.html

Heyligen, Joslyn (1992). Principia Cybernetica Web. Retrieved from What is System Theory?: http://pespmc1.vub.ac.be/SYSTHEOR.html 
com/hotwire/issue145/tooltips145.htm"

Joel Gunter. (2015, December 28). BBC News. Retrieved from Analysis of North Korea's computer system reveals spy files: http://www.bbc.com/news/world-asia-35188570

Ledesma, Lim, Miranda(2013). Research Congress. Retrieved from Crime Intelligence System: http://www.dlsu.edu.ph/conferences/dlsu_research_congress/2013/_pdf/HCT/HCT-I-008.pdf

Lind, D. M. (2005). VitsOrg. Retrieved from Contextual Understanding of Information Systems: http://www.vits.org/publikationer/dokument/550.pdf

McDermott, L. (2012). asahl. Retrieved from Implementation and Management of the Blended Learning Program at the University of the East, http://www.dlsu.edu.ph/conferences/asaihl/2012/_pdf/technical-papers-day1-PM/2-mcdermottimplementation-blended.pdf

Mirawati, Suminar (2013, November 11). Social Science Research Network. Retrieved from Student Appreciation Toward Online Learning Management System: A Study in Universitas Padjadjaran Indonesia: http://papers.ssrn.com/sol3/papers.cfm?abstract_id=2563946

Mitharam, Bohsale, Dagadu(2013, June 30). ImpactJournals. Retrieved from Impact of Computer: https://archive.org/details/1.EngImpactOfComputerMARATHE

Omogiade, N. S. (2014, January 2). HubPages. Retrieved from History of Computer System: http://hubpages.com/technology/History-of-Computer-System

Pollex, Johnson, Wood (2008). Canadian Journal of Nursing Informatics. Retrieved from Selecting a Learning Management System: http://cjni.net/Journal_original/Winter2008/pollex_johnson_wood_Pt2.pdf

Rahman, Ghazali, Ismail (2011, February 1). cis. Retrieved from The Effectiveness of Learning Management System (LMS) Case Study at Open University Malaysia (OUM), Kota Bharu Campus : http://www.cisjournal.org/Download_Feb_pdf_2.aspx

Rahman, Ghazali, Ismail (2011, February 1). cis. Retrieved from The Effectiveness of Learning Management System (LMS) Case Study at Open University Malaysia (OUM), Kota Bharu Campus : http://www.cisjournal.org/Download_Feb_pdf_2.aspx

Rashid, Majid, Yen (2012, October 14). Eprints. Retrieved from E-Learning Management System for Secondary School in Malaysia: http://eprints.usm.my/10941/1/ELearning_Management_System_for_Secondary_School_in_Malaysia_(PP_Sains_Komputer)).pdf

Rouse (2016). TechTarget. Retrieved from $\quad$ Fault http://searchdisasterrecovery.techtarget.com/definition/fault-tolerant

Pallab Dutta. (2016). eHow. Retrieved from The Importance of Computers in Business: http://www.ehow.com/facts_5586164_importance-computers-business.html

Pascual, Pasion, Ragual(2004). citeseerx. Retrieved from A Geographic Information System-Based Decision Support System for Mapping Philippine's Higher Education Institutions: http://citeseerx.ist.psu.edu/viewdoc/download?doi=10.1.1.111.3180\&rep=rep1\&type=pdf

Phelps, Michea (2003). ReserachGate. Retrieved from Learning Management Systems' Evaluation Focuses on Technology Not Learning: https://www.researchgate.net/publication/8916200_Learning_Management_Systems'_Evaluation_Focuses_o n_Technology_Not_Learning

Rajnulada. (n.d.). SlideShare. Retrieved from DepEd, Ched and TESDA: http://www.slideshare.net/rajnulada/deped-ched-and-tesda

Ramey, K. (2013, February 18). TechUcation. Retrieved from The Advantage of New Technology for Education: http://www.useoftechnology.com/technology-for-education/

Sabornie, E. J. (n.d.). UNC School of Education. Retrieved from Managing and Improving behavior in inclusive educational environments: http://www.learnnc.org/lp/editions/every-learner/6691

Samantha De Silva. (2015, February 10). The World Bank. Retrieved from The Impact of Education Management Information Systems: The Case of Afghanistan: https://blogs.worldbank.org/education/impacteducation-management-information-systems-case-afghanistan

Sauro, J. (2013, April 9). Measuring U. Retrieved from How to Measure Learnability: http://www.measuringu.com/blog/measure-learnability.php

Scheerens, J. (2014). nro.nl. Retrieved from Productive Time in Education: https://www.nro.nl/wpcontent/uploads/2014/09/PROO-Productive-time-in-education-Jaap-Scheerens-ea-def.pdf

Sidmach. (n.d.). Sidmach. Retrieved from Education Management Information System: www.sidmach.com/sidmach/EMIS.aspx

Shuttleworth, M. (2016). Quantitative Research Design. Retrieved from Explorable: https://explorable.com/quantitative-research-design

Skogberg, B. (2012). UX User Experience. Retrieved from How to measure learnability: http://ux.stackexchange.com/questions/26554/how-to-measure-learnability 
Star, T. P. (2012, December 24). PhilStar Global. Retrieved from Philippine Basic Education get boost with online learning: http://www.philstar.com/business-usual/2012/12/24/889333/philippine-basic-education-getsboost-online-learning

WebFinance Inc. (2016, February). BusinessDictionary. Retrieved from Computer System: http://www.businessdictionary.com/definition/computer-system.html 